\title{
GAMBARAN DISONANSI KOGNITIF PADA WANITA PEROKOK DEWASA MUDA BERPENDIDIKAN TINGGI
}

\author{
Rani Agias Fitri \\ Psychology Department, Faculty of Humanities, BINUS University \\ Jln. Kemanggisan Ilir III No 45, Kemanggisan-Palmerah, Jakarta Barat 11480 \\ rfitri@binus.edu
}

\begin{abstract}
This research aims to get the description of cognitive dissonance of high educated young adult smoker women, such as the source of dissonance and how to lessen their dissonance. By qualitative research method through depth interview with four research subjects, it is found out that logical inconsistency, general opinion, and past experience are the source of dissonance. Culture norm becomes the source of dissonance only on three subjects. The way the four subjects lessen their cognitive dissonance are changing behavior element and increasing cognitive element whereas changing cognitive element is only done by one subject.
\end{abstract}

Keywords: cognitive dissonance, smoker women, young adulthood, high educated

\begin{abstract}
ABSTRAK
Penelitian ini bertujuan untuk mengetahui gambaran disonansi kognitif pada perempuan perokok dewasa muda berpendidikan tinggi, seperti sumber disonansi dan cara mengurangi kondisi disonannya. Melalui metode penelitian kualitatif, dengan melakukan wawancara mendalam pada empat orang subjek, diketahui bahwa inkonsistensi logis, pendapat umum, dan pengalaman masa lalu merupakan sumber disonansi. Norma budaya menjadi sumber disonansi hanya pada tiga orang subjek. Cara yang dilakukan keempat subjek untuk mengurangi disonansi kognitifnya adalah mengubah elemen tingkah laku dan menambah elemen kognitif. Sedangkan mengubah elemen kognitif hanya dilakukan oleh seorang subjek.
\end{abstract}

Kata kunci: disonansi kognitif, wanita perokok, dewasa muda, pendidikan tinggi 


\section{PENDAHULUAN}

Jumlah perokok wanita di Indonesia meningkat pesat. Menurut data Komisi Nasional Pengendalian Tembakau, pada tahun 2010 jumlah wanita perokok sebesar 4,8 juta (Anonim, 2012). Jumlah tersebut telah meningkat 4 kali lipat dari tahun 1995, dengan jumlah wanita perokok pada tahun tersebut sebesar 1,1 juta.

Peningkatan jumlah wanita perokok tersebut dipengaruhi oleh keuntungan yang diperoleh dengan merokok. Bagi wanita, merokok dapat digunakan sebagai sarana mengontrol berat badan dan emosi (Harrell, Fredrickson, Pomerleau, \& Hoeksema, 2006). Kenikmatan yang diperoleh dengan merokok akan dirasakan segera dan berbeda dengan dampak negatifnya, yang dampak tersebut akan dirasakan bertahun-tahun kemudian (Leppel, 2006).

Merokok berdampak buruk terhadap kesehatan. Para perokok akan rentan terpapar kanker, terutama kanker paru, laring, faring, esophagus, dan rongga mulut (David \& Zion, 2009). Wanita perokok sendiri memiliki risiko yang lebih besar daripada pria perokok. Hal ini terkait dengan perbedaan fisiologis pada pria dan wanita. Wanita terpapar karsinogen dan racun lain dalam jumlah yang lebih besar dari pria, meskipun keduanya merokok dalam jumlah yang sama (Wardayati, 2011).

Risiko yang timbul dengan merokok seharusnya telah diketahui secara luas oleh masyarakat, termasuk wanita perokok berusia dewasa muda. Selain melalui artikel-artikel kesehatan, risiko merokok pun dicantumkan pada bungkus rokok. Merokok dapat menyebabkan gangguan kehamilan dan janin. Pada usia dewasa muda, wanita perokok dihadapkan pada tugas perkembangan yang penting, yaitu menjadi orangtua (Kail \& Cavanaugh, 2012). Dampak merokok terhadap kehamilan dan janin dapat memengaruhi tugas perkembangannya tersebut.

Sebagai seseorang yang mengikuti pendidikan tinggi, wanita perokok akan mampu berpikir rasional dan kritis dalam memahami pesan-pesan yang disampaikan tentang risiko merokok. Melalui akses yang dimiliki dalam perkuliahan, terbuka kesempatan bagi wanita perokok untuk mencari informasi akurat melalui jurnal dan buku di perpustakaan atau melalui internet.

Memahami risiko yang timbul karena merokok dan merasakan kenikmatan merokok, mendorong wanita perokok dewasa muda berpendidikan tinggi berada dalam kondisi disonan. Disonansi koginitif ini merupakan suatu keadaan terjadinya hubungan yang tidak sesuai antara elemen-elemen kognitif, yang dapat menimbulkan kejanggalan kognitif (Festinger, 1957). Ketidaksesuaian antara elemen-elemen kognitif yang dapat terjadi pada wanita perokok dewasa muda berpendidikan tinggi ini terlihat dari ketidaksesuaian antara elemen kesadaran mengenai efek samping merokok dengan elemen perilaku merokok yang mereka tampilkan. Keadaan disonansi ini dapat bersumber pada inkonsistensi logis (logical inconsistency), nilai-nilai budaya (cultural mores), pendapat umum (opinion generality), dan pengalaman masa lalu (past experience) (Festinger, 1957).

Disonansi ini akan menimbulkan ketidaknyamanan secara psikologis (Eliot \& Devine, dalam Allahyani, 2012). Sebagai suatu bentuk ketegangan, individu akan termotivasi untuk mengatasinya agar semua elemen kognitif dapat bersesuaian kembali (konsonan). Terdapat beberapa cara yang dapat digunakan untuk mengatasi keadaan disonan tersebut, yaitu mengubah elemen tingkah laku, mengubah elemen kognitif lingkungan, dan menambah elemen kognitif baru (Festinger, 1957). 


\section{METODE PENELITIAN}

Penelitian ini menggunakan metode penelitian kualitatif dengan teknik wawancara secara mendalam. Wawancara dilakukan dua sampai tiga kali pada setiap subjek, dengan durasi setiap wawancara adalah 90 menit. Sebelum melakukan wawancara, peneliti membina raport dengan subjek. Prosedur pengambilan sampel menggunakan purposeful sampling. Kriteria subjek dalam penelitian ini adalah sebagai berikut: wanita dewasa muda berusia 20 sampai 40 tahun; mengikuti jenjang pendidikan tinggi program sarjana, minimal strata satu; merokok baik ringan, sedang, maupun berat yang dilihat dari jumlah konsumsi rokok per hari.

\section{HASIL DAN PEMBAHASAN}

Berikut gambaran karakteristik keempat subjek penelitian dalam penelitian ini.

Tabel 1 Gambaran Subjek Penelitian

\begin{tabular}{|c|c|c|c|c|}
\hline DATA & SUBJEK 1 & SUBJEK 2 & SUBJEK 3 & SUBJEK 4 \\
\hline Nama & Yuli & Lili & Kiki & Ika \\
\hline Usia & 22 Tahun & 22 Tahun & 29 Tahun & 27 Tahun \\
\hline Agama & Islam & Katholik & Islam & Islam \\
\hline Status & Berpacaran & Berpacaran & Berpacaran & Berpacaran \\
\hline Tempat tinggal & Depok & Jakarta Selatan & Jakarta Selatan & Jakarta Timur \\
\hline Tinggal dengan & Sendiri (Kost) & $\begin{array}{l}\text { Keluarga } \\
\text { (orangtua) }\end{array}$ & $\begin{array}{l}\text { Keluarga } \\
\text { (orangtua) }\end{array}$ & Keluarga (orangtua) \\
\hline Suku & Jawa-Palembang & $\begin{array}{l}\text { Bali Banten- } \\
\text { Betawi Cina }\end{array}$ & Jawa-Sunda & Medan-Sunda Padang \\
\hline $\begin{array}{l}\text { Anak ke....dari } \\
\text {....bersaudara }\end{array}$ & $1 / 3$ & $1 / 2$ & $8 / 8$ & $1 / 4$ \\
\hline $\begin{array}{l}\text { Jumlah rata-rata } \\
\text { konsumsi rokok } \\
\text { /hari }\end{array}$ & $\begin{array}{l}\text { 1-5 batang rokok } \\
\text { (Perokok ringan) }\end{array}$ & $\begin{array}{l}10-20 \text { batang } \\
\text { rokok } \\
\text { (Perokok sedang) }\end{array}$ & $\begin{array}{l}\text { 1-10 batang rokok } \\
\text { (Perokok ringan) }\end{array}$ & $\begin{array}{l}\text { 10-15 batang rokok } \\
\text { (Perokok sedang) }\end{array}$ \\
\hline Pekerjaan & $\begin{array}{l}\text { Bekerja part time, } \\
\text { mengajar di } \\
\text { activity class dan } \\
\text { les privat. }\end{array}$ & Tidak bekerja & $\begin{array}{l}\text { Bagian proyek } \\
\text { pembangunan } \\
\text { gedung } \\
\text { perusahaan } \\
\text { telekomunikasi }\end{array}$ & $\begin{array}{l}\text { Account Manager } \\
\text { perusahaan Internet }\end{array}$ \\
\hline Pendidikan & $\begin{array}{l}\text { Mahasiswi FISIP } \\
\text { sebuah PTN di } \\
\text { Jakarta, semester } 8 \\
\text { (Program S1) }\end{array}$ & $\begin{array}{l}\text { Mahasiswi } \\
\text { Fakultas Psikologi } \\
\text { sebuah PTN di } \\
\text { Jakarta, semester } \\
8 \text { (Program S1) }\end{array}$ & $\begin{array}{l}\text { Fakultas Teknik } \\
\text { Sipil di sebuah } \\
\text { PTS di Jakarta } \\
\text { (Lulusan S1) }\end{array}$ & $\begin{array}{l}\text { Information } \\
\text { Technology dan } \\
\text { Marketing di sebuah } \\
\text { universitas di New } \\
\text { Zealand (Lulusan S2) }\end{array}$ \\
\hline Merk rokok & Sampoerna A Mild & Marlboro Lights & Marlboro Menthol & Marlboro Menthol \\
\hline
\end{tabular}

*Nama samaran, ${ }^{*}$ PTN $=$ Perguruan Tinggi Negeri, $*$ PTS $=$ Perguruan Tinggi Swasta

\section{Elemen-elemen Disonansi Kognitif}

Pada keempat subjek wanita dewasa muda berpendidikan tinggi ditemukan adanya penyangkalan dari satu elemen yang diikuti atau mengikuti suatu elemen yang lain. Penyangkalan tersebut berupa penyangkalan elemen kognitif terhadap elemen perilaku, yaitu elemen kognitif yang 
dimiliki subjek tentang kesadaran dampak merokok terhadap kesehatan bertentangan dengan elemen perilaku merokoknya. Seperti yang dikemukakan oleh Shaw \& Constanzo (1970), adanya penyangkalan dari satu elemen yang diikuti oleh atau mengikuti suatu elemen lain akan mendorong terjadinya disonansi. Dapat dikatakan bahwa keempat subjek penelitian mengalami kondisi disonansi.

\section{Sumber-sumber Disonansi Kognitif}

Tabel 2 Sumber Disonansi Kognitif pada Subjek

\begin{tabular}{|c|c|c|c|c|}
\hline Sumber & Lili & Kiki & Ika & Yuli \\
\hline $\begin{array}{l}\text { Inkonsistensi } \\
\text { logis }\end{array}$ & $\begin{array}{l}\text { Efek samping } \\
\text { merokok tidak } \\
\text { sesuai dengan } \\
\text { perilaku } \\
\text { merokoknya }\end{array}$ & $\begin{array}{l}\text { Kesadaran akan } \\
\text { adanya efek samping } \\
\text { dari merokok }\end{array}$ & $\begin{array}{l}\text { Kesadaran mengenai } \\
\text { efek samping dari } \\
\text { rokok }\end{array}$ & $\begin{array}{l}\text { Menilai wanita } \\
\text { perokok sebagai } \\
\text { wanita nakal dengan } \\
\text { perilaku merokoknya } \\
\text { Larangan Ibu agar } \\
\text { Yuli tidak merokok } \\
\text { dengan perilaku } \\
\text { merokok ibu }\end{array}$ \\
\hline Nilai budaya & - & $\begin{array}{l}\text { Penerimaan } \\
\text { masyarakat Indonesia } \\
\text { dengan masyarakat } \\
\text { luar negeri }\end{array}$ & $\begin{array}{l}\text { Penerimaan } \\
\text { masyarakat Indonesia } \\
\text { terhadap wanita } \\
\text { perokok berbeda } \\
\text { dengan penerimaan } \\
\text { masyarakat luar } \\
\text { negeri }\end{array}$ & $\begin{array}{l}\text { Perbedan penerimaan } \\
\text { antara masyarakat } \\
\text { Jakarta dengan } \\
\text { masyarakat } \\
\text { Purwokerto, Solo, dan } \\
\text { Yogyakarta terhadap } \\
\text { wanita perokok }\end{array}$ \\
\hline $\begin{array}{l}\text { Pengalaman } \\
\text { masa lalu }\end{array}$ & $\begin{array}{l}\text { Sakit tenggorokan } \\
\text { yang berbeda dari } \\
\text { sebelumnya } \\
\text { (mengeluarkan } \\
\text { darah) }\end{array}$ & $\begin{array}{l}\text { Perlakuan ibunya } \\
\text { terhadap kakak } \\
\text { perempuan Kiki yang } \\
\text { ketahuan merokok }\end{array}$ & $\begin{array}{l}\text { Setelah bekerja Ika } \\
\text { merasakan perbedaan } \\
\text { dalam menampilkan } \\
\text { perilaku merokoknya } \\
\text { dibandingkan ketika } \\
\text { masih kuliah dulu }\end{array}$ & $\begin{array}{l}\text { Kenikmatan merokok } \\
\text { yang dirasakannya } \\
\text { pada saat mulai } \\
\text { merokok aktif, } \\
\text { sekarang sudah tidak } \\
\text { dirasakan lagi }\end{array}$ \\
\hline $\begin{array}{l}\text { Pendapat } \\
\text { umum }\end{array}$ & $\begin{array}{l}\text { Ibu yang tidak } \\
\text { senang perilaku } \\
\text { merokoknya }\end{array}$ & $\begin{array}{l}\text { Penerimaan } \\
\text { masyarakat Indonesia } \\
\text { yang kurang baik } \\
\text { terhadap wanita } \\
\text { perokok }\end{array}$ & $\begin{array}{l}\text { Pandangan laki-laki } \\
\text { yang lebih menyukai } \\
\text { wanita yang tidak } \\
\text { merokok untuk } \\
\text { dijadikan pacar } \\
\text { daripada wanita yang } \\
\text { merokok }\end{array}$ & $\begin{array}{l}\text { Pendapat dari } \\
\text { orangtua, adik, dan } \\
\text { pacar yang tidak } \\
\text { menyukai wanita } \\
\text { perokok }\end{array}$ \\
\hline
\end{tabular}

Menurut Festinger (Sarwono, 1995), terdapat empat sumber disonansi, yaitu inkonsistensi logis, nilai-nilai budaya, pendapat umum, dan pengalaman masa lalu. Inkonsistensi logis terjadi pada keempat subjek. Hal ini terjadi ketika kenikmatan yang dirasakan dari merokok tidak konsisten dengan kesadaran akan dampak merokok pada kesehatan. Inkonsistensi logis juga terjadi ketika subjek memiliki penilaian bahwa wanita perokok adalah wanita nakal, sedangkan dirinya sendiri merokok dan dirinya bukanlah wanita nakal. Gawronski (2012) mengemukakan bahwa secara konsep kata yang berlawanan akan menyebabkan ketidakkonsistensian kognitif apabila menyangkut pada objek yang sama. Kata berlawanan disini adalah nakal dan tidak nakal, sedangkan objeknya adalah perempuan perokok. Selain itu, inkonsistensi logis muncul ketika subjek dilarang merokok oleh ibunya, padahal ibunya sendiri perokok.

Sumber disonansi berupa nilai-nilai budaya muncul pada ketiga subjek. Hal ini terjadi ketika subjek mengalami berada di dua budaya yang berbeda, yaitu budaya Indonesia dengan budaya luar negeri, dan budaya Jakarta dengan budaya daerah. Kedua budaya tersebut menampilkan nilai 
penerimaan yang berbeda tentang perempuan perokok. Satu orang subjek tidak mengalami sumber disonansi kognitif berupa nilai-nilai budaya, karena subjek tersebut belum merasakan berada di budaya lain, selain Jakarta.

Pengalaman masa lalu yang berbeda dengan pengalaman saat ini menjadi sumber disonansi kognitif pada keempat subjek. Pengalaman masa lalu tersebut bervariasi, seperti pengalaman dampak kesehatan yang berbeda, pengalaman mendapat perlakuan yang berbeda karena merokok, pengalaman perubahan perilaku merokok, dan perubahan kenikmatan dalam merokok. Secara lebih jelas pada salah satu subjek sakit tenggorokan yang dulu pernah dialami akibat merokok berbeda dengan yang sekarang dialami. Sakit tenggorokan saat ini menimbulkan dahak berdarah sedangkan yang dulu tidak.

Sumber disonansi berupa pendapat umum terjadi pada keempat subjek. Hal ini terjadi ketika orang lain, terutama significant others, seperti ibu, saudara, dan pacar, menyatakan ketidaksetujuannya terhadap perlaku subjek. Namun, sumber disonansi pendapat umum ini tidak hanya berasal dari significant others, tetapi juga masyarakat umum (Indonesia) dan laki-laki.

\section{Cara Mengatasi Disonansi Kognitif}

Tabel 3 Cara Mengatasi Disonansi Kognitif pada Subjek

\begin{tabular}{|c|c|c|c|c|}
\hline Cara Mengatasi & Lili & Kiki & Ika & Yuli \\
\hline $\begin{array}{l}\text { Mengubah elemen } \\
\text { tingkah laku }\end{array}$ & $\begin{array}{l}\text { Mengurangi } \\
\text { konsumsi rokok }\end{array}$ & $\begin{array}{l}\text { Mengurangi } \\
\text { konsumsi rokok }\end{array}$ & $\begin{array}{l}\text { Mengurangi } \\
\text { konsumsi rokok }\end{array}$ & $\begin{array}{l}\text { Mengurangi } \\
\text { konsumsi rokok }\end{array}$ \\
\hline $\begin{array}{l}\text { Mengubah elemen } \\
\text { kognitif }\end{array}$ & - & $\begin{array}{l}\text { Meyakinkan } \\
\text { kakaknya untuk } \\
\text { tidak melaporkan } \\
\text { perilaku } \\
\text { merokoknya kepada } \\
\text { ibunya }\end{array}$ & - & - \\
\hline $\begin{array}{l}\text { Menambah } \\
\text { elemen kognitif }\end{array}$ & $\begin{array}{l}\text { Dosen merokok tapi } \\
\text { tetap sehat } \\
\text { meskipun telah } \\
\text { berumur }\end{array}$ & $\begin{array}{l}\text { Padang merupakan } \\
\text { daerah yang belum } \\
\text { maju dan sangat } \\
\text { fanatik, sehingga } \\
\text { bagi masyarakat di } \\
\text { sana wanita yang } \\
\text { merokok bukanlah } \\
\text { sesuatu yang wajar. }\end{array}$ & $\begin{array}{l}\text { Pria memandang } \\
\text { wanita perokok sok } \\
\text { modern }\end{array}$ & $\begin{array}{l}\text { Ibunya yang } \\
\text { merokok sejak } \\
\text { SMA tetapi tetap } \\
\text { bisa memiliki anak }\end{array}$ \\
\hline
\end{tabular}

Festinger (1957) mengemukakan tiga cara yang dapat digunakan untuk mengurangi disonansi, yaitu: mengubah eleman tingkah laku, mengubah elemen kognitif lingkungan, dan menambah elemen kognitif baru. Mengubah elemen tingkah laku dilakukan oleh ketiga subjek dengan mengurangi perilaku merokoknya (jumlah konsumsi rokok). Menurut Festinger (1957), mengubah elemen tingkah laku akan dilakukan ketika disonansi terjadi antara elemen yang berhubungan dengan pengetahuan mengenai lingkungan (elemen lingkungan) dan elemen tingkah laku. Metode ini sendiri sering dilakukan untuk mengurangi disonansi, sehingga tidak mengherankan apabila dilakukan oleh keempat subjek.

Mengubah elemen kognitif dapat dilakukan dengan mengubah situasi yang berhubungan dengan elemen tersebut (Festinger, 1957). Cara inilah yang juga digunakan oleh satu orang subjek dalam mengurangi disonansinya. Subjek membujuk kakaknya untuk tidak melaporkan perilaku merokoknya pada ibu mereka. Subjek yang lain tidak menggunakan cara ini untuk mengurangi disonansinya, karena menurut Festinger (1957) cara ini tidaklah semudah mengubah elemen tingkah 
laku. Untuk dapat menggunakan cara ini, subjek harus memiliki kontrol terhadap lingkungannya. Tidak mudah bagi subjek untuk mengubah situasi yang tidak mendukung menjadi mendukung perilaku merokoknya.

\section{Resistensi untuk Mengubah Perilaku Merokok}

Meskipun subjek penelitian telah berusaha mengurangi disonansinya dengan berhenti merokok atau mengurangi jumlah konsumsi merokoknya, ternyata sering kali cara ini tidak berhasil mereka lakukan. Hal ini menunjukkan adanya resistensi untuk mengubah elemen tingkah laku seperti yang diungkapkan oleh Festinger (1957). Resistensi ini terjadi karena perubahan perilaku merokok ini akan menyakitkan atau menimbulkan kerugian bagi subjek penelitian. Berhenti atau mengurangi merokok membuat subjek harus menahan keinginan merokoknya, terutama pada saat ia melihat orang lain merokok. Hal ini bukan merupakan kondisi menyenangkan buat mereka. Ketika subjek merasa tidak tahan lagi dengan keadaan itu, maka mereka pun tidak mengubah elemen tingkah lakunya dengan kembali lagi merokok seperti biasanya. Resistensi juga terjadi karena tampilnya perilaku merokok memuaskan bagi subjek penelitian. Meskipun subjek menyadari merokok akan berdampak buruk, tetapi karena merokok menyenangkan bagi mereka, mereka pun memilih untuk terus merokok. Selain itu, resistensi juga terjadi jika tidak mungkin untuk membuat perubahan tingkah laku merokok secara mudah. Merokok yang telah menjadi kebiasaan membuat subjek sulit untuk mengubahnya. Hal ini terjadi karena jika subjek tidak melakukan kebiasaannya itu mereka akan merasakan ada sesuatu yang hilang.

\section{Kadar Disonansi}

Meskipun Festinger (1957) tidak menunjukkan bagaimana cara pasti untuk menentukan kadar disonansi yang dialami seseorang, peneliti akan mencoba untuk menentukan kadar disonansi dari subjek penelitian dengan memerhatikan tingkat kepentingan elemen-elemen yang saling berhubungan dengan perilaku merokok bagi subjek penelitian. Menurut asumsi peneliti, aspek pendapat pribadi, pendapat teman dekat (pacar), pendapat orangtua, pendapat teman laki-laki, pendapat masyarakat, dan aspek kesehatan merupakan aspek yang penting bagi subjek penelitian. Maka, peneliti pun memerhatikan aspek-aspek tersebut mengetahui kadar disonansi dari subjek penelitian. Secara lebih lanjut lagi akan dijelaskan sebagai berikut.

\section{Pendapat Pribadi}

Adanya pendapat pribadi yang negatif terhadap wanita yang merokok menyebabkan Yuli dan Lili mengalami disonansi ketika pada kenyataannya mereka sendiri kemudian juga merokok. Akan tetapi, dibandingkan dengan Lili, sebenarnya kadar disonansi Yuli lebih tinggi. Hal ini terlihat dari pernyataan Yuli ketika pertama kali merokok ia "benar-benar" merasakan dirinya telah menjadi wanita nakal. Sedangkan subjek yang lain (Kiki dan Ika) tidak mengalami disonansi karena mereka tidak mempunyai pandangan yang negatif terhadap wanita yang merokok. Dari sebelum mulai merokok sampai sekarang, Kiki dan Ika mempunyai pandangan yang biasa saja terhadap wanita yang merokok.

\section{Pendapat Teman Dekat (Pacar)}

Dari keempat subjek penelitian, hanya Yuli dan Ika yang mengalami disonansi karena pendapat pacar. Pada dasarnya pacar mereka sebenarnya tidak suka terhadap wanita yang merokok, terlebih lagi untuk dijadikan pacar. Namun, kadar disonansi yang dialami Yuli lebih besar daripada yang dialami Ika, karena sebenarnya pacar Yuli itu tidak mau menjadikan Yuli sebagai pacar jika tahu Yuli masih merokok. Sedangkan yang terjadi pada Ika; meskipun pacarnya lebih menyukai wanita yang tidak merokok untuk dijadikan pacar tetapi pacarnya itu bisa menerima keadaan Ika yang 
merokok. Pacar Ika juga tidak pernah melarang Ika untuk merokok. Bahkan mereka sering merokok bersama-sama.

\section{Pendapat Orangtua}

Orangtua yang tidak menyetujui merokok yang dilakukan subjek, menyebabkan semua subjek mengalami disonansi. Namun, kadar disonansi Yuli dan Lili lebih tinggi dibandingkan dengan kadar disonansi Kiki dan Ika. Hal ini terlihat dari bagaimana Yuli yang merasa sangat bersalah dan tidak enak kepada orangtuanya. Sebagai anak perempuan satu-satunya ia merokok, dan adik-adiknya yang laki-laki semua justru tidak merokok. Sedangkan Lili, kadar disonansinya tinggi karena sampai sekarang ibunya selalu menunjukkan ketidaksukaannya terhadap merokok yang dilakukan Lili secara terang-terangan.

Pada Kiki, kadar disonansinya tidak terlalu tinggi karena ia merasa yakin kalau sebenarnya ibunya telah tahu ia merokok. Jika suatu hari ibunya benar-benar tahu kalau ia merokok, baginya tidak menjadi masalah lagi karena ia bisa menjelaskan secara baik-baik kepada ibunya. Ika juga sangat yakin kalau sebenarnya ayahnya telah tahu kalau ia merokok. Hanya saja selama ini ayahnya belum pernah memergokinya sedang merokok. Ibu Ika telah tahu kalau Ika merokok, dan ia hanya menasihati Ika untuk berhenti merokok. Selama ini Ika cukup bebas untuk merokok di rumahnya.

\section{Pendapat Teman Laki-Laki}

Keempat subjek menyadari adanya pandangan negatif laki-laki terhadap wanita yang merokok. Akan tetapi, hanya Yuli dan Ika yang mengalami disonansi karena hal tersebut. Lili tidak mengalami disonansi karena ia cenderung menghindarinya. Ia malas berteman, apalagi menjadikan pacar, dengan laki-laki yang memandang rendah wanita hanya karena merokok. Sedangkan Kiki tidak mengalami disonansi karena sejauh ini teman-teman laki-laki yang berada di lingkungannya tidak memandang rendah wanita yang merokok.

Di antara Yuli dan Ika, disonansi yang dialami oleh Yuli lebih tinggi. Pandangan negatif lakilaki terhadap wanita yang merokok itu telah membuat Yuli merasa takut jika ada laki-laki yang menyukainya akan berubah menjadi tidak suka hanya karena Yuli merokok.

\section{Pendapat Masyarakat}

Pada dasarnya semua subjek menyadari adanya pandangan negatif dari masyarakat terhadap wanita yang merokok, karena dalam lingkungan kecil mereka saja, seperti keluarga dan teman-teman, banyak yang mempunyai pandangan negatif terhadap wanita yang merokok. Bahkan ada di antara mereka sendiri yang mempunyai pandangan negatif terhadap wanita yang merokok, tetapi tidak semua subjek penelitian mengalami disonansi karena pendapat masyarakat ini. Lili tidak mengalami disonansi karena ia cenderung tidak memedulikan pendapat masyarakat. Ia hanya memedulikan pendapat orang-orang yang ada di lingkungannya dan orang-orang yang dikenalnya. Jika ada orang yang memerhatikannya ketika sedang merokok di tempat umum, Lili tidak menghiraukannya. Ia merasa tidak kenal dan tidak ada urusan dengan orang tersebut, sehingga bagi Lili pendapat orang tersebut tidak akan berpengaruh terhadapnya.

Dari tiga subjek (Yuli, Kiki, \& Ika), Kiki mengalami kadar disonansi yang paling tinggi. Kiki pernah mengalami kejadian yang tidak menyenangkan sewaktu di Padang karena merokok. Ketika berada di sebuah restoran Kiki merokok, dan ternyata ia diperhatikan oleh semua pegawai restoran tersebut. Keadaan ini membuat Kiki merasa risih dan bersalah karena telah salah tempat merokok. Meskipun pernah mengalami diperhatikan orang-orang ketika sedang merokok di tempat umum, tetapi apa yang dialami oleh Yuli dan Ika tidaklah setidakmenyenangkannya pengalaman Kiki. 


\section{Kesehatan}

Sejak sebelum merokok semua subjek penelitian telah mengetahui adanya efek samping merokok terhadap kesehatan. Pengetahuan yang mereka miliki tersebut semakin lama semakin bertambah. Bahkan setelah merokok mereka sendiri telah merasakan gangguan kesehatan dan perubahan-perubahan yang terjadi pada dirinya. Maka tidak dapat dihindari lagi terjadinya disonansi kognitif pada diri mereka. Kadar disonansi yang dialami oleh Lili dan Ika (sama-sama termasuk perokok sedang) lebih tinggi dibandingkan dengan Yuli dan Kiki (sama-sama perokok ringan). Kadar disonansi Yuli dan Kiki tidak terlalu tinggi karena selama ini mereka belum pernah mengalami gangguan kesehatan akibat merokok. Mereka hanya merasakan adanya perubahan-perubahan karena merokok, seperti nafas lebih pendek, suara lebih berat, kuku menjadi kuning, bibir hitam, dan kulit kering.

Dibandingkan dengan Ika, dari hasil penelitian diketahui bahwa Lili mengalami disonansi yang lebih tinggi. Hal ini terjadi karena pada saat pengambilan data dilakukan Lili sedang mengalami disonansi. Disonansi yang dialaminya oleh Lili ini disebabkan oleh keputusannya untuk berhenti merokok karena sakit tenggorokan yang parah. Pada saat sedang berhenti merokok ini, sebenarnya Lili masih ingin terus merokok, dan ia merasa kesal karena gara-gara sakit tenggorokannya itu ia menjadi tidak bisa merokok. Ika sendiri meskipun juga pernah mengalami gangguan kesehatan karena merokok, tetapi gangguan kesehatannya tersebut tidak separah yang dialami Lili. Ia hanya kadangkadang merasakan dadanya sakit saat sedang bernafas, dan biasanya ia dapat segera mengatasinya dengan membuka pakaian dalamnya dan tiduran.

\section{SIMPULAN}

Pada subjek penelitian yang berjumlah empat orang ditemukan terjadinya proses disonansi kognitif terhadap perilaku merokoknya. Sumber disonansi pada keempat subjek adalah inkonsistensi logis (logical inconsistency), pendapat umum (opinion generality), dan pengalaman masa lalu (past experience). Sumber disonansi berupa nilai budaya (cultural mores) hanya ditemukan pada tiga subjek. Subjek mengurangi disonansinya dengan cara mengubah elemen tingkah laku, mengubah elemen kognitif (elemen lingkungan dan elemen sendiri), dan menambah elemen kognitifnya. Cara mengurangi disonansi dengan mengubah elemen tingkah laku dan menambah elemen kognitif dilakukan oleh keempat subjek penelitian. Namun cara mengurangi disonansi dengan mengubah elemen kognitif hanya dilakukan oleh satu orang subjek.

\section{Saran}

Penelitian selanjutnya dapat menggunakan metode penelitian kuantitatif untuk mendapatkan jumlah subjek yang lebih banyak, sehingga dapat diketahui sumber disonansi yang sering terjadi dan cara mengurangi disonansi yang sering digunakan oleh subjek dengan karakteristik wanita perokok dewasa muda yang berpendidikan tinggi. Selain itu, dengan metode penelitian kuantitatif akan lebih mudah diperbandingkan disonansi kognitif berkaitan perilaku merokok yang terjadi pada subjek wanita dengan subjek laki-laki.

Mengingat tidak mudah bagi subjek menghilangkan perilaku merokoknya, maka dapat dilakukan penelitian yang bertujuan mengetahui self identity pada perokok. Perilaku merokok tampaknya telah menjadi bagian dari self identity subjek, sehingga sulit untuk menghentikan perilaku merokoknya. Namun hal ini tentu saja membutuhkan pengujian secara empiris. 


\section{DAFTAR PUSTAKA}

Allahyani, M- H. A. (2012). The Relationship Between Cognitive Dissonance \& Decision Making Styles in Sample of Female Students at The University of Umm Al Qura. Journal Education, Spring; 132; 3, pg 607.

Anonim. (18 Juni 2012). Perokok Wanita di Indonesia Meningkat Empat Kali. Diunduh tanggal 20 Juli 2012 dari http://www.merdeka.com/peristiwa/perokok-wanita-di-indonesia-meningkatempat-kali.html.

David, N.B. \& Zion, U. B. (2009). Factor Affecting Smoking Tendency \& Smoking Intensity. Journal of Health Education, 109, No 3, pp : 193-212.

Festinger. (1957). A theory of cognitive dissonance. California: Stanford Universitas Press.

Gawronski, B. (2012). Back to the Future of Dissonance Theory: Cognitive Consistency as Core Motive. Journal Social Cognition Vol 30, No 6, pp 652-668.

Harrell, Fredrickson, Pomerleau \& Hoeksema. (2006). The Role of Trait Self Objectification in Smoking Among College Women. Journal of Sex Role 54: 735 - 743

Kail, V., \& Cavanaugh, C. (2012). Human development: A life span View. $6^{\text {th }}$ Edition. USA : Wadsworth.

Leppel, K. (2006). The Relationship Between College Class and Cigarette Smoking. Journal of Health Education, 107, 1, pg 63-80.

Mitchell, G. (1969). A dictionary of Sociologi. London :Rutdlege \& Kegan Paul.

Sarwono, S. W. (1995) Teori-teori Psikologi Sosial. Jakarta: Rajawali Pers.

Shaw, M. E. \& Constanzo, P. R. (1970). Theories of Social Psychology. USA: Mc Graw Hill.

Wardayati, K. T. (15 Agustus 2011). Merokok Lebih Bahaya pada Wanita. Diunduh tanggal 20 Juli 2012 dari http://intisari-online.com/read/merokok-lebih-berbahaya-pada-wanita. 